\title{
Construction and Implementation of the Five Levels, Staged and Step-by-step Practical Teaching System
}

\author{
Jian-Jun Yang ${ }^{a}$, Chang-He Lib and Ji-Wen $\operatorname{Tan}^{\mathrm{c}}$ \\ School of Mechanical Engineering, Qingdao Technological University, Qingdao 266520, China \\ ayjjdem@163.com, bsy_lichanghe@163.com, ctanfanye@sina.com
}

Keywords: Practical teaching system, Project teaching method, CDIO, Science and technology innovation

\begin{abstract}
Practical teaching is an important teaching link to train students' practice and innovation ability and comprehensive quality. At present, there are still some problems and shortcomings in the practical teaching. Aiming at the problems, we constructed the five levels, staged and step-by-step practical teaching system. Project teaching method is adopted based on CDIO teaching idea, and the knowledge learning and ability training are realized simultaneously. Through the science and technology innovation, students' comprehensive ability has been further promoted. Students' employment rate and competition performance have been improved, it is proved that the practice education effect is remarkable.
\end{abstract}

\section{Introduction}

In recent years, the difficult employment of college graduates has become a social problem of common concern, and one of the main reasons is that recruitment companies do not like the only empty talk [1]. Therefore, in order to push students to the society successfully, we must strengthen the training of students' practical ability.

Practical teaching is an important teaching link to train students' practical ability and comprehensive quality. Compared with theoretical teaching, practical teaching is more intuitive, practical, comprehensive and innovative, which has a direct impact on the quality of personnel training [2, 3]. Practical teaching plays an extremely important role in training students' innovative consciousness, students' engineering consciousness and enhancing the ability of college students' social adaptation.

In recent years, all colleges take practical and effective measures, and actively carry out teaching practice, increase the investment in laboratory construction, improve the experimental teaching conditions. Those measures have a positive impact on improving the practice and innovation ability of the students. But at present, there are still some problems and shortcomings in the practical teaching, it's mainly behaved in: the understanding of the role of practical teaching needs to be further improved, the practical skill training system that related to theoretical teaching is lack, the open sharing of practical teaching resources and the construction of teaching staff should be further improved, students' engineering quality and innovation ability need to be further improved [4].

In view of the above problems and deficiencies, we actively carry out teaching research and reform, and adhere to the educational idea of practice education, construct the practical teaching system in order to highlight the students' engineering quality and practical ability, improve the teaching methods, the quality of practical teaching is ensured, and good teaching effect is obtained.

\section{Basic Framework of the Practical Teaching System}

To improve the students' engineering quality, in the relationship between imparting knowledge and quality training, we should change the situation that the traditional education is mainly based on imparting knowledge, establish the ideas that focus on quality education, and integrated with the imparting knowledge, cultivating ability and improving quality. On the relationship between theory and practice, we should change the status that pay attention to theory, despise practice, ignore the 
application in the past, establish the ideas that combine theory with practice, strengthen practical education, pay attention to engineering application. In the relationship between teaching and learning, we should change the situation that the teacher as the main body, all around the teacher, the teacher to teach what, students learn what, establish the ideas that the students are the main body of the teaching activity, pay more attention to the cultivation of students' independent learning ability and innovative spirit.

Combining theoretical teaching, experimental teaching, project implementation, exercitation, and extends to extracurricular science and technology innovation activities, so the five levels, staged and step-by-step practical teaching system is formed, and it's systematic, holistic, coordinated and unified. The structure diagram is shown in Figure 1.

\begin{tabular}{|l|l|}
$\begin{array}{l}\text { Science and } \\
\text { technology } \\
\text { innovation }\end{array}$ & $\begin{array}{l}\text { Skills competition, science and technology competition, student } \\
\text { independent research program. } \\
\text { Enhance students' professional quality and innovation ability, and } \\
\text { cultivate the enterprise competencies. }\end{array}$ \\
$\begin{array}{l}\text { Engineering } \\
\text { practice. }\end{array}$ & $\begin{array}{l}\text { Graduation design, one level and two level projects, working practice. } \\
\text { Training students' engineering consciousness, engineering thought, } \\
\text { team cooperation ability, innovation ability, communication ability. }\end{array}$ \\
$\begin{array}{l}\text { Experiment } \\
\text { combining with } \\
\text { the project. }\end{array}$ & $\begin{array}{l}\text { Three level projects related to the curriculum. } \\
\text { To cultivate students' ability to analyze and solve problems, so that } \\
\text { students can have innovative thinking and innovative spirit. }\end{array}$ \\
$\begin{array}{l}\text { Comprehensive } \\
\text { experiment. }\end{array}$ & $\begin{array}{l}\text { Disassembly experiment, professional comprehensive experiment. } \\
\text { To cultivate students' innovative consciousness, comprehensive } \\
\text { innovation ability and practical ability. }\end{array}$ \\
$\begin{array}{l}\text { Basic } \\
\text { experiment. }\end{array}$ & $\begin{array}{l}\text { It is set up in the course of theory. } \\
\text { Developing students' basic learning methods and skills. }\end{array}$ \\
\hline
\end{tabular}

Fig. 1 The five levels, staged and step-by-step practical teaching system

\section{Experimental Teaching}

The construction of experimental teaching system is related to the quality of personnel training. In order to realize the organic combination of experimental teaching and theoretical teaching, embody the basic principles of the ability, personality and the cultivation of innovative consciousness in the experimental teaching. In the construction of experimental teaching system, according to the actual situation of the students in different learning stages, the staged and modular experimental teaching system is adopted, and the hierarchical and personalized training model is emphasized.

On the basis of optimizing the course system and integrating the teaching content, we improve the proportion of the integrated teaching content of theory and practice, improve the proportion of comprehensive, design and innovative experiments, and reconstruct the experimental content system, design and increase new experiments of ability training.

\section{Project Teaching Method Based on CDIO}

Drawing on the concept and model of CDIO engineering education [5], the innovation personnel training mode of whole process management is constructed, in that the student as the main body, the curriculum project as the basis, comprehensive project as the core, project driven as the main line, the organic integration of theory and practice, knowledge, ability, quality in one. 
Through the implementation of the project, the organic integration of the theoretical system, experimental and practical teaching is realized in one or more courses, and the two processes of knowledge learning and ability training are realized simultaneously, the principle as shown in Figure 2.

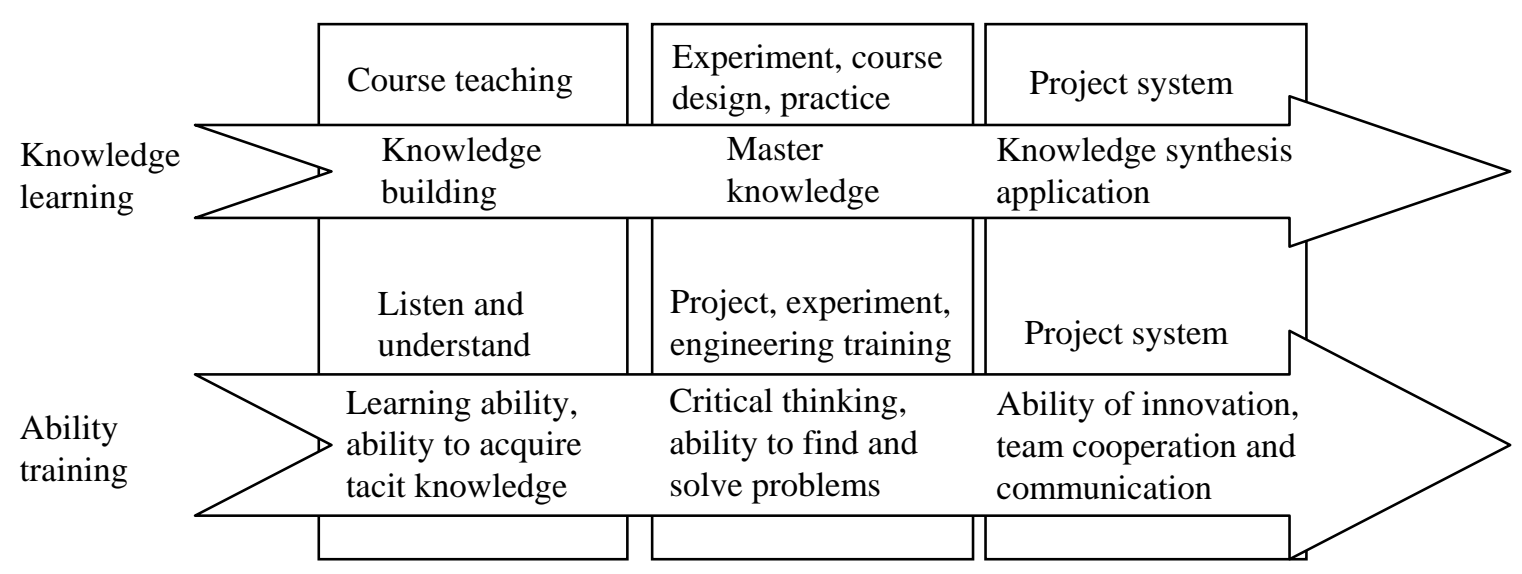

Fig. 2 Knowledge learning and ability training based on project driven

In order to ensure the smooth implementation of the project, the following measures need to be taken. (1) Compress the theoretical class hours of course, in order to carry out the project, experiment and other practical teaching. (2) Set up three level projects in professional basic courses and core professional courses. (3) Set up two level projects in professional course group.

For example, we designed a three level project about electronic scale in the course of electrical control and PLC, and designed a two level project about robot in the numerical control course group. Students can get a systematic training. When the machining real object is difficult in some courses, virtual simulation projects are also carried out.

In the course of project driven teaching, under the teacher's guidance, students in the group to use the knowledge and skills to solve the problem under the new situation, students' knowledge and skills are enhanced, the ability to analyze and solve problems is improved. The whole process is real, and it is a reflection of real life, thus students' learning is more pertinent and practical, students have learned the skills necessary to obtain employment or entrepreneurship in the future, including practical ability, analytical ability, comprehensive ability, dealing with emergency ability, communication ability, cooperation ability and the ability to solve practical problems.

\section{Science and Technology Innovation}

Skill competition and science and technology competition have a special educational function that can't be played in daily teaching, and have a unique and irreplaceable role in improving students' practical ability, cultivating students' innovative ability, and improving the teaching level [6]. Building the skills competition and science and technology competition platform, constructing the new training model of college students' innovation ability, aim to establish a long-term working mechanism, form a series of, full and brand of the subject contest, make skill competition and science and technology competition become the effective way to train applied talents.

We add innovative credits in the professional training program, to encourage students to take part in various disciplines competition, skill competition, science and technology competition, creative competition, scientific research or educational reform activities of the teachers, extracurricular scientific activities in open laboratory, academic report, etc, in their spare time.

In the choice of skill competition projects, mainly consider improving the practical ability, consolidating the results of classroom teaching and practice, carry out series of skill competitions, and turner, fitter and CAD as the main content. In each of the specific competitions, the training of students' engineering quality is the starting point. 
The training on practices and innovative ability laid a good foundation for employment or entrepreneurship of students.

\section{Teaching Effectiveness}

Through the reform and innovation of practical teaching, graduates have solid foundation, strong ability, and high quality, and have been praised by the employer and the society. According to the survey, the employer's satisfaction rate for the graduates of our school is more than $95 \%$. In the past two years, the primary employment rate of graduates is more than 93\%. 76 students receive 24 national and provincial awards in 2015, participate in the science and technology competitions include national mechanical design innovation contest, challenge cup college students' science and technology competition, creative design competition of mechanical and electrical products for college students in Shandong Province, etc.

\section{Summary}

In order to cultivate students' practice and innovation ability, we constructed the five levels, staged and step-by-step practical teaching system. The system integrates theoretical teaching, experimental teaching, project implementation based on CDIO, exercitation, and science and technology innovation activities. Students can get a comprehensive training, and the comprehensive quality of the students has been improved.

\section{Acknowledgement}

In this paper, the research was sponsored by the research project of teaching reform in undergraduate colleges in Shandong Province (Project No. 2015M087).

\section{References}

[1] C.S. Wang, Z.L. Han, J.Y. Shi, Innovating practice teaching system of giant mechanical discipline for the need of talent cultivation, Research and exploration in Laboratory, 2007, 26(12):9-12.

[2] C.H. Xu, Y.B. Shi, P. Zhang, G.C. Xiao, B. Fang, Thinking and preliminary practice of engineering capability in mechanical specialty, Journal of Linyi University, 2014, 36(6):21-23.

[3] Q.L. Zhang, G.J. Liu, The innovation based on practice application in engineering education, Modern Manufacturing Technology and Equipment, 2010,(6):77-78.

[4] C.H. Li, Y.L. Hou, G.Y. Liu, Expanding of college students' scientific quality and innovation with the carrier of research program, Advanced Materials Research, 2011, 171-172: 90-94.

[5] W.Y. Chen, The research of the teaching mode based on the concept of CDIO architectural design, Applied Mechanics \& Materials, 2014, 584-586: 2753-2756.

[6] H.Z. Xu, M.L. Li, Exploration and practice on the cultivation of undergraduates' scientific and technological innovation ability, Journal of East China Institute of Technology(Social Science), 2009, 28(3):294-297. 